\title{
Evaluation of factors affecting employee performance: The case of government employees in Oman
}

\section{Nasreddine Saadouli ${ }^{a^{*}}$ and Maryam Yousuf Obaid Al-Khanbashi ${ }^{b}$}

${ }^{a}$ Faculty of Business, Sohar University, Sultanate of Oman

${ }^{b}$ HR Manager, Governorate of Muscat, Sultanate of Oman

\section{H R O N I C L E}

\section{Article history:}

Received: November 18, 2020

Received in revised format:

December 282020

Accepted: January 12, 2021

Available online:

January 12, 2021

Keywords:

Employee performance

Organizational change

Public administration

Oman

Technology

\section{A B S T R A C T}

There is a universal consensus that improving employee performance is a cornerstone for any organization's path to success and prosperity. However, when it comes to identifying what factors trigger such an improvement, there is anything but consensus among researchers. In this paper, a sample of government employees in the Sultanate of Oman is studied to discern the factors that affect employee performance. A factor analysis is applied to validate the constructs used to measure the various variables. A correlation analysis and a corresponding multiple linear regression is carried out to test the hypotheses. In contrast to many research findings, the results indicate that the only significant factor is technology; whereas leadership and organizational structure are neutral. The results are analyzed and discussed in view of the socio-cultural context of the Sultanate of Oman and the GCC region.

C 2021 by the authors; licensee Growing Science, Canada

\section{Introduction}

Improving employee performance is vital to any organization's success and sustainability (De Jonge \& Peeters, 2019). The question of how to positively impact such performance has triggered rich debates on the factors and mediators. Countless studies identified a large slew of factors ranging from abstract constructs such as organizational commitment and the workplace environment (Kurniawan \& Heryanto, 2019; Rahayu, Rasid, \& Tannady, 2019), to more tangible variables such as salary and title (Ekhsan, Aeni, Parashakti, \& Fahlevi, 2019). The factors diverge even further when considering government employees in a developing country, as is the case of the Sultanate of Oman. Besides the human capital challenges (Mohamed, 2020), the government jobs in oil-rich, developing countries have always served a social welfare objective of distributing the wealth generated by the natural resource (Al-Mejren, 2019). However, the rapidly growing population coupled with declining oil revenues in recent years have forced these countries to reconsider their public sector employment paradigm and inculcate more accountability in the hiring and retention decisions (Boughanmi \& Khan, 2019; Shayah \& Sun, 2019).

Consequently, adopting research results from studies carried out in different settings could prove futile. For instance, assuming that factors that motivate employees in the United States are the same that motivate employees in another part of the World could lead to a significant gap between management expectations and actual employee performance. The pitfalls of such a "reasoning by analogy" are numerous and profound (Davies, 1988). Furthermore, investing in such measures would result in inefficient allocation of scarce resources since the objectives are not aligned with the means or the causes. This is even more challenging when considering public organizations, where in most cases the emphasis is more on efficient resource usage in lieu of revenue generation. The challenge is magnified in developing countries where transparent and effective systems for measuring employee performance are typically lax if they exist at all. For GCC countries, Oman included, the challenge is further magnified by what has been termed the social welfare role of employment (Zaidan, Al-Saidi, \& Hammad, 2019).

\footnotetext{
* Corresponding author.

E-mail address: saadouli1971@yahoo.fr (N. Saadouli) 
It is in this complex setting that this study is carried out. Guided by previous research in similar settings, an initial decision was made regarding which factors to consider in this study. In line with the exploratory nature of this exposition, only three factors were considered: leadership, technology and the organizational structure. The effect of these factors on employee performance is critically evaluated to show the extent to which widely accepted research findings apply in the context of a developing GCC country such as the Sultanate of Oman. After a focused literature review, the problem is stated with the corresponding conceptual model and research hypotheses. That is then followed by a description of the methodology and an analysis of the results. The key findings and decision-making implications are presented and discussed. Research limitations and future directions conclude the exposition.

\section{Literature review}

The literature review is used to achieve a two-pronged objective: state the main research findings and arrive at a definition of the variables and factors that have been widely accepted and used. This is of critical importance since it impacts directly the design of the research instrument (questions in questionnaire).

\subsection{Employee Performance}

Employee performance is central to the success of organizations, public or private (Lorincová, Štarchoň, Weberová, Hitka, \& Lipoldová, 2019). The complex human nature makes improving performance an elusive target due to the many, interconnected and often difficult to measure, behavioural and organizational factors ( Jeste \& Lee, 2019 ). Generally, performance is positively correlated with reward, intrinsic or extrinsic, and motivation (Diseth et al., 2020; Liu et al., 2020; Rida \& Siddiqui, 2019; Fischer et al. 2019) to mention a few). A recurring definition of employee (job) performance is the time-constrained level of effort to carry out activities and maintain standards (Khan, Yusoff, Hussain, \& Ismail, 2019). As such, items measuring performance should highlight these aspects. A widely used tool for measuring performance is the one developed by Patterson (1990), Dordunu et al. (2020), Davoud et al. (2019) and Saadouli and Al-Khanbashi (2020).

\subsection{Leadership}

Leaders play an essential role in moving organizations effectively and efficiently towards their goals (Abdullahi, Anarfo, \& Anyigba, 2020). By mobilizing the organization to share in their visions, leaders have the potential to transform organizations' fates and make the difference between utter failure and flamboyant success (Krause \& Miller, 2020). Arguably, leaders achieve these objectives by, among other initiatives, positively impacting employee performance (Shafi, Zoya, gLei, Song, \& Sarker, 2020). Research has shown that, in most cases, employee performance improves with positively perceived leadership roles and changes (Yue, Men, \& Ferguson, 2019). In particular, leaders' ability to motivate employees by setting challenging goals and promoting creativity (Afsar \& Umrani, 2019), and to provide them with clear instructions and guidance (Frémeaux \& Pavageau, 2020), are favourably perceived by employees.

\subsection{Technology}

Technology has justifiably appeared in many research studies as either a primary factor or a mediating factor in improving employee performance (Alyoubi \& Yamin, 2019; Nam, 2019). The difference depends on the nature of the organization's reliance on technology for its operations, and the type of employees and the extent to which technology interferes with their tasks and duties (Delpechitre, Black, \& Farrish , 2019). Technological changes have been studied extensively in recent research studies due to the information technology revolution that marked the end of the $20^{\text {th }}$, and the beginning of the $21^{\text {st }}$ century (Morgan, 2019). The far reaching impact of the Internet and mobile applications on the business landscape have certainly led to significant impact on employee performance ( Sanchez, 2019). Technology can improve employee performance in two broad ways: the first, and obvious, manifestation is if technology makes the duties more effective and efficient (Burnett \& Lisk, 2019); the second, and perhaps less obvious, is technology's ability to instil a new-found urge to learn and develop among employees which leads to motivation to perform better (Lemmetty \& Collin, 2020).

\subsection{Organizational Structure}

Organizational structure plays a pivotal role in employee performance since it specifies two key dimensions without which employee performance would be impossible to gauge: authority and communication channels (Ahmetoglu, Scarlett, Codreanu, \& Chamorro-Premuzic , 2019). Without proper authority channels, employees would not be able to match duties to supervisor's expectations (Diamantidis \& Chatzoglou, 2019). Similarly, without proper communication channels, employees would be tormented between inconsistent flows of information and ambiguous tasks and duties. Research has shown with good levels of significance that clear authority structure improves performance through the identification of boundaries and responsibilities (Cookson, Hazeltine, \& Schumacher, 2020). Having a clear chain of command eliminates ambiguities in the organizational processes and eliminates, or at least minimizes, inefficient use of resources. Additionally, with well-defined communications' channels, employees have a more efficient access to necessary information and guidance, leading to a higher 
likelihood of correct, first-attempt, accomplishment of tasks (Nzewi, Yan, \& Olutuase, 2019). This will lead to improved performance driven by the increased efficiency.

\subsection{Oman and the GCC Setting}

Oman is a developing country that is geographically located in the southern and eastern part of the Arabian Peninsula. Politically, Oman is a member of the Gulf Cooperation Council (GCC) sharing many of its historical and cultural specifications. In particular, the GCC states share a common economic reliance on oil. This is both a blessing and a challenge. It is a blessing in the sense that this highly demanded commodity provides these countries with significant revenues that are used in developing the human capital and the required infrastructure. It is a challenge, however, in the context of government employment since it has been viewed by many as a social welfare mechanism of distributing the oil wealth (Bazoobandi \& Alexander, 2020). This perception led to significant issues since performance has not been associated with any meaningful factors except for the abundance of the revenues generated by the natural resource. Furthermore, in recent years, oil revenues have dropped considerably while the populations of these countries have risen significantly with a sizable young, employment seeking, population (Karolak, Mirza, \& Mishrif, 2020). To measure up to these new realities, governments in the GCC have been scrambling to modify their economic landscape by reducing dependence on oil (Nasir, Al-Emadi, Shahbaz, \& Hammoudeh, 2019), and introducing new performance-related criteria for government employment recruitment and retention (Albalushi, Zaidan, Bin Abdul Khadir, \& Bin Yusof, 2019). It is in this context that the present study is carried out. The purpose is to determine if indeed the three factors investigated affect employee performance. The results of the study would help governments in the GCC, and Oman in particular, target the relevant factors with better-designed development and retention schemes and more focused resource allocations.

There are many factors that affect employee performance. A key and recurring factor reported in the literature has been the role of leadership. Whether it is in the context of change management or organizational change, leadership seemed to consistently play a pivotal role in improving employee performance, even in the public sector. Research within the GCC context has also confirmed this finding in many studies involving public offices and administrations. Consequently, the first hypothesis of the study will be as follows:

\section{$\mathrm{H}_{1}$ : Leadership is positively associated with Omani government employee performance.}

To improve employee performance, technological tools must be provided to employees in order to accomplish their duties. Hence, technology has been shown in the literature to play a significant role in improving employee performance. Technology has been used in the literature as a primary or a mediating variable. Despite the administrative nature of the jobs of the people involved in the study, it has been decided to consider technology as a direct, rather than a mediating, factor affecting employee performance. Hence, the second hypothesis of the study is:

\section{$\mathrm{H}_{2}$ : Technology is positively associated with Omani government employee performance.}

The clarity of the authority and communication channels depicted by the organizational structure provides the basis for a proper evaluation of the employee performance. Essentially, performance would be negatively affected if the directives and guidelines given to the employees are ambiguous. Furthermore, any mismatch between the targets set by the management and the duties undertaken by the employees would lead to an unfair assessment of employee performance. Research has shown with high degrees of confidence that the organizational structure plays a significant role in affecting employee performance. Consequently, the third hypothesis of the study is:

\section{$\mathrm{H}_{3}$ : The organizational structure is positively associated with Omani government employee performance.}

\section{Research Methodology}

The proposed research model is presented in Fig. 1. The present research focuses on studying the relationship between the three identified factors and employee performance. The study involved polling a random sample of employees at the Governorate of Muscat office in Oman.

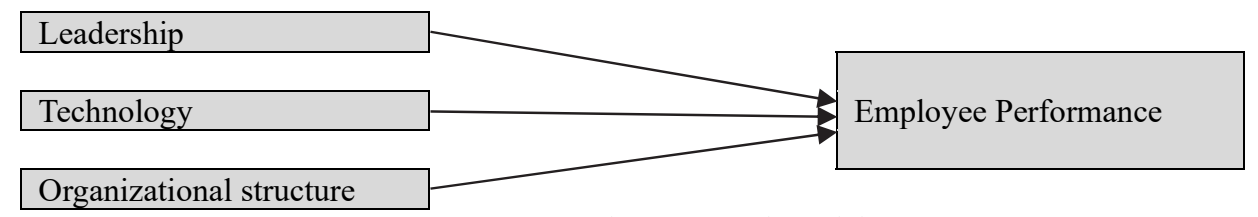

Fig. 1. Proposed Conceptual Model

A systematic random sample of 200 employees was selected. A self-administered questionnaire was written in English with available Arabic translation when requested. The data was collected during the spring of 2020 (March-April) at the beginning 
of the Covid-19 pandemic spread and consequent lock down. This may explain the lower than the expected response rate, as only 100 of the employees provided complete and usable responses (50\% response rate).

\section{Results}

Despite the fact that the questionnaire was self-administered to increase the response rate, only 100 complete and valid responses were collected. A Pearson's correlation analysis was carried out with coefficients and significance levels provided in Table 1.

Table 1

The results of correlations

\begin{tabular}{|c|c|c|c|c|c|}
\hline & & Performance & Structure & Leadership & Technology \\
\hline \multirow[t]{3}{*}{ Performance } & Pearson Correlation & 1 & .070 & .115 & $.309^{* *}$ \\
\hline & Sig. (2-tailed) & & .491 & .254 & .002 \\
\hline & $\mathrm{N}$ & 100 & 100 & 100 & 100 \\
\hline \multirow[t]{3}{*}{ Structure } & Pearson Correlation & .070 & 1 & $.439^{* *}$ & .077 \\
\hline & Sig. (2-tailed) & .491 & & .000 & .447 \\
\hline & $\mathrm{N}$ & 100 & 100 & 100 & 100 \\
\hline \multirow[t]{3}{*}{ Leadership } & Pearson Correlation & .115 & $.439^{* *}$ & 1 & $.279^{* *}$ \\
\hline & Sig. (2-tailed) & .254 & .000 & & .005 \\
\hline & $\mathrm{N}$ & 100 & 100 & 100 & 100 \\
\hline \multirow[t]{3}{*}{ Technology } & Pearson Correlation & $.309^{* *}$ & .077 & $.279^{* *}$ & 1 \\
\hline & Sig. (2-tailed) & .002 & .447 & .005 & \\
\hline & $\mathrm{N}$ & 100 & 100 & 100 & 100 \\
\hline
\end{tabular}

**. Correlation is significant at the 0.01 level (2-tailed).

As seen in Table 1, Performance is only significantly correlated with technology with a coefficient of 0.309 . On the other hand, in addition to its significant correlation with performance, technology is also significantly correlated with leadership (coefficient 0.279 ). Finally, the organizational structure is only significantly correlated with leadership (coefficient 0.439 ).

\subsection{Factor Analysis}

In order to validate the association of items to the four variables and to fine-tune the items measuring each variable, a factor analysis was carried out. Table 2 presents the measure of sampling adequacy.

Table 2

KMO and Bartlett's Test

\begin{tabular}{ccr} 
Kaiser-Meyer-Olkin (KMO) Measure of Sampling Adequacy. & & 0.734 \\
Bartlett's Test of Sphericity & Approx. Chi-Square & 865.643 \\
& $\mathrm{df}$ & 190 \\
& $\mathrm{Sig}$ & 0.000 \\
\hline
\end{tabular}

Since the KMO is greater than 0.6 providing a good basis for conducting a factor analysis. Furthermore, Bartlett's test of sphericity is significant and hence there is evidence that variables are not orthogonal, i.e. they are correlated. Starting with a factor analysis with all 20 items included indicated cross-loading issues as shown in Table 3. The extraction method used is Principal Component Analysis and the Rotation Method is Varimax with Kaiser Normalization. By eliminating the items with the most significant cross-loading problems, the following four concepts (corresponding to the four variables) were identified and are presented in Table 3.

Table 3

The results of rotated component matrix

\begin{tabular}{|c|c|c|c|c|}
\hline & \multicolumn{4}{|c|}{ Component } \\
\hline & 1 & 2 & 3 & 4 \\
\hline Q10 & .903 & & & \\
\hline Q9 & .858 & & & \\
\hline Q7 & .803 & & & \\
\hline Q8 & .747 & & & \\
\hline Q13 & & .860 & & \\
\hline Q12 & & .826 & & \\
\hline Q11 & & .798 & & \\
\hline Q3 & & & .839 & \\
\hline Q4 & & & .801 & \\
\hline Q5 & & & .695 & \\
\hline Q2 & & & .595 & \\
\hline Q19 & & & & .786 \\
\hline Q17 & & & & .780 \\
\hline Q20 & & & & .754 \\
\hline
\end{tabular}


Since most of the items were adapted from previous research studies, the reliability of the instrument has been established. As for the scale reliability, the coefficient of internal consistency known as Cronbach's Alpha has been used. Table 4 provides a summary of the reliability statistics.

Table 4

The results of Reliability Statistics

\begin{tabular}{ccc}
\hline Variable & Number of items & Cronbach's Alpha \\
\hline Employee performance & 4 & 0.733 \\
Leadership & 4 & 0.888 \\
Technology & 3 & 0.808 \\
Organizational structure & 3 & 0.748 \\
\hline
\end{tabular}

All alpha values exceed 0.7 which validates the inter-item consistency of the instrument used.

\subsection{Multiple Linear Regression}

To test the conceptual model in Fig. 1, a multiple linear regression model is developed and tested for significance. From the correlation analysis, we have already shown that some factors are pair-wise correlated; however, linear regression investigates the relationship between the dependent variable (employee performance) and the three independent factors simultaneously. The ANOVA summary is presented in Table 5.

Table 5

The results of ANOVA test

\begin{tabular}{llllll}
\hline Model & Sum of Squares & df & Mean Square & F & 3.461 \\
\hline Regression & 2.197 & 3 & .732 & .019 \\
Residual & 20.306 & 96 & .212 & \\
\hline Total & 22.503 & 99 & & \\
\hline
\end{tabular}

The linear model is significant at the 0.05 level. The coefficients are presented in Table 6 .

Table 6

The results of regression analysis

\begin{tabular}{|c|c|c|c|c|c|c|c|}
\hline \multicolumn{2}{|c|}{ Unstandardized Coefficients } & \multirow{2}{*}{\multicolumn{2}{|c|}{$\begin{array}{c}\text { Standardized Coefficients } \\
\text { Beta }\end{array}$}} & \multirow{2}{*}{$\mathrm{t}$} & \multirow{2}{*}{ Sig. } & \multicolumn{2}{|c|}{ Collinearity Statistics } \\
\hline $\mathrm{B}$ & Std. Error & & & & & Tolerance & VIF \\
\hline (Constant) & 3.256 & 0.433 & & 7.525 & 0 & & \\
\hline Leadership & 0.008 & 0.071 & 0.013 & 0.118 & 0.907 & 0.747 & 1.338 \\
\hline Technology & 0.256 & 0.086 & 0.302 & 2.987 & 0.004 & 0.92 & 1.087 \\
\hline Structure & 0.027 & 0.073 & 0.041 & 0.376 & 0.708 & 0.805 & 1.241 \\
\hline
\end{tabular}

By inspecting the coefficients, it is evident that only technology has a significant coefficient. After running the multiple linear regression with the stepwise method, we obtain the results in Tables 7 through Table 9.

Table 7

The results of ANOVA test for $\mathrm{EP}=\mathrm{f}(\mathrm{T})$

\begin{tabular}{|c|c|c|c|c|c|c|}
\hline \multicolumn{2}{|c|}{ Model } & Sum of Squares & $\mathrm{df}$ & Mean Square & $\mathrm{F}$ & Sig. \\
\hline \multirow[t]{3}{*}{1} & Regression & 2.146 & 1 & 2.146 & 10.331 & $.002^{\mathrm{b}}$ \\
\hline & Residual & 20.357 & 98 & .208 & & \\
\hline & Total & 22.503 & 99 & & & \\
\hline
\end{tabular}

Table 8

The results of regression analysis for $E P=f(T)$

\begin{tabular}{|c|c|c|c|c|c|c|c|}
\hline \multirow{2}{*}{ Model } & \multicolumn{2}{|c|}{ Unstandardized Coefficients } & \multirow{2}{*}{$\frac{\text { Standardized Coefficients }}{\text { Beta }}$} & \multirow[b]{2}{*}{$\mathrm{t}$} & \multirow{2}{*}{ Sig. } & \multicolumn{2}{|c|}{ Collinearity Statistics } \\
\hline & $\mathrm{B}$ & Std. Error & & & & Tolerance & VIF \\
\hline (Constant) & 3.366 & .367 & & 9.184 & .000 & & \\
\hline Technology & .262 & .081 & .309 & 3.214 & .002 & 1.000 & 1.000 \\
\hline
\end{tabular}

Table 9

The results when the variable is excluded for from $\mathrm{EP}=\mathrm{f}(\mathrm{L}, \mathrm{T}, \mathrm{S})$

\begin{tabular}{|c|c|c|c|c|c|c|c|}
\hline \multirow[b]{2}{*}{ Model } & \multirow[b]{2}{*}{ Beta In } & \multirow[b]{2}{*}{$\mathrm{t}$} & \multirow[b]{2}{*}{ Sig. } & \multirow[b]{2}{*}{ Partial Correlation } & \multicolumn{3}{|c|}{ Collinearity Statistics } \\
\hline & & & & & Tolerance & VIF & Minimum Tolerance \\
\hline Leadership & .032 & .314 & .754 & .032 & .922 & 1.084 & .922 \\
\hline Structure & .046 & .477 & .634 & .048 & .994 & 1.006 & .994 \\
\hline
\end{tabular}


The values from the correlation analysis and the multiple linear regression indicate that for every unit of change in technology, the employee performance increases by $26 \%$. The positive relationship between EP and T is significant at the 0.01 level. This provides the evidence for accepting $H 2$.

On the other hand, the correlation values and the multiple linear regression clearly show that leadership and organizational structure are not positively associated with employee performance. The two variables (L and S) have been excluded from the multiple linear regression model. Hence, both hypotheses $H 1$ and $H 3$ cannot be accepted.

\section{Discussion}

Table 10 summarizes the decisions reached for the hypotheses tested in the study. Only technology emerged as a significant factor that positively affects employee performance for government employees in Oman. What makes this result striking is the mount of research ascertaining the role of leadership and organizational structure in motivating employees and positively affecting their performance. Given the clerical nature of many of the government jobs, it is not surprising that technology is perceived as having positive influence on the performance. On the other hand, in a highly bureaucratic management structure characterizing most government offices, it is ironic that the clarity of the organizational structure in such a system is not contributing to efficiency and perceived higher performance. As for the leadership, being rated as neutral may be the result of the perception that government leadership roles are typically assigned based on political loyalty rather than competence or leadership ability.

\section{Table 10}

Hypotheses Tests

\begin{tabular}{ll}
\hline Hypothesis & Decision \\
\hline H1: Leadership is positively associated with Omani government employee performance & Not accepted \\
H2: Technology is positively associated with Omani government employee performance & Accept \\
H3: the organizational structure is positively associated with Omani government employee performance & Not accepted \\
\hline
\end{tabular}

Nonetheless, it would be imprudent to rationalize the results without taking the socio-cultural context into account. Oman, along with the other GCC nations, has been blessed with significant natural oil reserves. As mentioned in the introduction, government employment has been perceived by some as a means to distribute the wealth, and consequently comes with little or no expectations on performance. The results indicate that despite the changing economic forces, especially the current decrease in oil revenues, the overall perspective has not changed significantly when it comes to the perception of leadership and the organizational structure. Both of these factors are still rated as neutral in terms of their effect on performance. On the other hand, the fact that technology is considered a significant factor in improving performance indicates that the efficiency aspect of the job is being considered seriously.

The implications of the results can be classified as short and long term. In the short term, it is clear that changing leadership or modifying the authority and communication channels will have little or no effect on the employee performance. Consequently, and in the face of tight budgets, it is advisable for government offices to invest in efficiency-improving technologies. In the long term, however, no significant impact on employee performance can be achieved through improving efficiency only. The motivational aspect of leaders and the streamlining potential of organizational structures must play a more rigorous role in improving employee performance. This can be accomplished through continuous training and development of the employees and the leaders. For the employees, the focus would be on instilling in them a sense of merit-based approach to the job, and the urge to elevate performance relative to the duties that are expected. For the managers, the emphasis should be on expanding their role beyond the traditional purely administrative and managerial role to that of a team leader. The study can be used by government planners to determine the short-term investment priorities as well the long-term training and development goals. Migrating to a performance and merit-based government employment paradigm is the only way ahead for Oman and other GCC nations as oil revenues keep falling and local employment requirements keep rising. However, governments need to carefully go through this path while balancing the need to efficiently and effectively use the country's resources versus the social repercussions that could follow such a move if it were swift and unplanned. The Middle East, to which Oman and the GCC belong to, has been undergoing what has been named the "Arabian Spring" where some of its causes stem from the perceived injustice in the distribution of the common wealth.

\section{Conclusion}

Employee performance is an essential ingredient for the success and sustainability of organizations, whether private or public. Government employees in Oman and the GCC have enjoyed lifelong employment with little or no expectations on performance for the past few decades. However, and due to the declining oil revenues and increasing national job seekers, Oman has been faced with the challenge of maximizing employee performance in order to efficiently use the ever-decreasing available resources. In this study, only three factors have been addressed: leadership, technology and organizational structure. The results indicate the significance of the technology factor only and thus attesting to the fact that the perception of government employment has not changed as significantly as hoped for. The results can be used to better plan for the short as well as the 
long term horizons. In particular, in the short term the emphasis should be on investing in efficiency-improving technologies; whereas in the long term, the focus should be on redefining, and communicating effectively to the employees, the perception of government employment to become more performance and merit based.

\section{Limitations and future research}

The study is based on a relatively small sample that focused on just three factors. Larger samples and more factors may lead to a better understanding of the government employment landscape in Oman. Understanding what other factors motivate government employees to perform better, such as pay and benefits, will help in designing performance evaluation schemes that rewards employees for embracing the changing employment paradigm. The current study also focused on the Muscat area in generating the sample. This could limit the generalizability of the results since Muscat is a large metropolitan city as opposed to the other parts of Oman. Future research will consider these venues, and others, to better understand the issue and provide the decision makers with a more complete picture to prepare future development plans.

\section{References}

Abdullahi, A., Anarfo, E., \& Anyigba, H. (2020). The impact of leadership style on organizational citizenship behavior: does leaders' emotional intelligence play a moderating role? Journal of Management Development, 39(9/10), 963-987.

Afsar, B., \& Umrani, W. A. (2019). Transformational leadership and innovative work behavior: The role of motivation to learn, task complexity and innovation climate. European Journal of Innovation Management 23(3), $402-428$.

Ahmetoglu, G., Scarlett, L., Codreanu, S.-C., \& Chamorro-Premuzic, T. (2019). The impact of organizational structure and work autonomy in fostering entrepreneurial tendencies and job performance. Evidence-based HRM 8(1), 128-143.

Albalushi, A., Zaidan, A., Bin Abdul Khadir, F. A., \& Bin Yusof, M. (2019). Competency Management in the Context of Omani Civil Service Reform \& Development. International Business Research 12(4), 76-89.

Al-Mejren, A. A. (2019). Credibility of growth and development measures in rentier economies: The case of GCC. Journal of Economics and Development Studies, 7(4), 83-100.

Alyoubi, B. A., \& Yamin, M. Y. (2019). The impact of task technology fit on employee job. Marketing and Management of Innovations, 4, 140-159.

Bazoobandi, S., \& Alexander, R. (2020). GCC Oil Wealth: The Power and the People. In I. P. Series, The New Regional Order in the Middle East (pp. 27-48). Palgrave Macmillan, Cham.

Boughanmi, H., \& Khan, M. A. (2019). Welfare and distributional effects of the energy subsidy reform in the Gulf cooperation council countries: The case of Sultanate of Oman. International Journal of Energy Economics and Policy 9(1), 228-236.

Burnett, J. R., \& Lisk, T. C. (2019). The future of employee engagement: Real-time monitoring and digital tools for engaging a workforce. International Studies of Management \& Organization, 49(1), 108-119.

Cookson, S. L., Hazeltine, E., \& Schumacher, E. H. (2020). Task structure boundaries affect response preparation. Psychological Research, 84(6), 1610-1621.

Davies, T. (1988). Determination, Uniformity, and Relevance: Normative Criteria for Generalization and Reasoning by Analogy. In D. T.R., Analogical Reasoning (pp. 227-250 https://doi.org/10.1007/978-94-015-7811-0_11). Dordrecht: Springer.

Davoud, T. S., Ehsan, A., \& Mooris, S. (2019). Examining the impact of causal effect of core self-evaluation, job autonomy and occupational hardiness on teachers job performance. Journal of Educational Measurement and Evaluation Studies, 9(25), 199-228.

De Jonge, J., \& Peeters, M. (2019). The Vital Worker: Towards Sustainable Performance at Work. International Journal of Environmental Resource Public Health, 16, 910.

Delpechitre, D., Black, H. G., \& Farrish , J. (2019). The dark side of technology: examining the impact of technology overload on salespeople. Journal of Business \& Industrial Marketing, 34(2), 317-337.

Diamantidis, A. D., \& Chatzoglou, P. (2019). Factors affecting employee performance: an empirical approach. International Journal of Productivity and Performance Management, 68(1), 171-193.

Diseth, Å., Mathisen, F. K., \& Samdal, O. (2020). A comparison of intrinsic and extrinsic motivation among lower and upper secondary school students. Educational Psychology 40(8), 961-980.

Dordunu, W., Owusu, G., \& Simpson, S. (2020). Turnover intentions and job performance of accountants: The role of religiosity and spiritual intelligence. Journal of Research in Emerging Markets, 2(1), 43-61.

Ekhsan, M., Aeni, N., Parashakti, R., \& Fahlevi, M. (2019). The impact of motivation, work satisfaction and compensation on employee's productivity in coal companies. 2019 1st International Conference on Engineering and Management in Industrial System (ICOEMIS 2019) (pp. 406-415). Atlantis Press.

Fischer, C., Malycha, C., \& Schafmann, E. (2019). The Influence of Intrinsic Motivation and Synergistic Extrinsic Motivators on Creativity and Innovation. Frontiers in Psychology, 10, 137, doi: 10.3389/fpsyg.2019.00137.

Frémeaux, S., \& Pavageau, B. (2020). Meaningful Leadership: How Can Leaders Contribute to Meaningful Work?. Journal of Management Inquiry, doi:10.1177/1056492619897126.

Jeste, D. V., \& Lee, E. E. (2019). Emerging empirical science of wisdom: Definition, measurement, neurobiology, longevity, and interventions. Harv Rev Psychiatry, 27(3), 127-140.

Karolak, M., Mirza, C., \& Mishrif, A. (2020). Nationalization of GCC Labor Markets: The Changing Role of Higher Education in the Era of the 4th Industrial Revolution. (pp. 1-8). Gulf Research Center Cambridge. 
Khan, M. A., Yusoff, R. M., Hussain, A., \& Ismail, F. B. (2019). The mediating effect of job satisfaction on the relationship of HR practices and employee job performance: Empirical evidence from higher education sector. International Journal of Organizational Leadership 8, 78-94.

Krause, R., \& Miller, T. L. (2020). From strategic leaders to societal leaders: On the expanding social role of executives and boards. Journal of Management 46(8), 1315-1321.

Kurniawan, H., \& Heryanto, H. (2019). Effect of work discipline and work environment on employee performance with work motivation as an intervening variable in department of tourism, youth and sport of Padang District. Archives of Business Research, 7(7), 88-101.

Lemmetty, S., \& Collin, K. (2020). Self-directed learning as a practice of workplace learning: Interpretative repertoires of self-directed learning in ICT work. Vocations and Learning, 13, 47-70.

Liu, Y., Hau, K.-T., Liu, H., Wu, J., Wang, X., \& Zheng, X. (2020). Multiplicative effect of intrinsic and extrinsic motivation on academic performance: A longitudinal study of Chinese students. Journal of Personality 88(3), 584-595.

Lorincová, S., Štarchoň, P., Weberová, D., Hitka, M., \& Lipoldová, M. (2019). Employee Motivation as a Tool to Achieve Sustainability of Business Processes. Sustainability, 11, 3509.

Mohamed, S. E. (2020). Challenges and potentiality of GCC countries towards achieving sustainable economic growth: Analytical framework. European Journal of Business and Innovation Research, 8(5), 23-37.

Morgan, J. (2019). Will we work in twenty-first century capitalism? A critique of the fourth industrial revolution literature. Economy and Society, 48(3), 371-398.

Nam, T. (2019). Technology usage, expected job sustainability, and perceived job insecurity. Technological Forecasting and Social Change, 138, 155-165.

Nasir, M. A., Al-Emadi, A. A., Shahbaz, M., \& Hammoudeh, S. (2019). Importance of oil shocks and the GCC macroeconomy: A structural VAR analysis. Resources Policy, 61, 166-179.

Nzewi, O. I., Yan, B., \& Olutuase, S. (2019). An analysis of the design factors of work procedures: implications for local government administration in South Africa. International Review of Administrative Sciences, 0020852319868829.

Rahayu, M., Rasid, F., \& Tannady, H. (2019). The effect of career training and development on job satisfaction and its implications for the organizational commitment of regional secretariat (SETDA) employees of Jambi Provincial Government. International Review of Management and Marketing 9(1), 79-89.

Rida, N., \& Siddiqui, D. (2019). Impact of motivation on employees performance in Pakistan. Business Management and Strategy, 10(1), 1-22.

Saadouli, N., \& Al-Khanbashi, M. Y. (2020). Factors affecting performance of government employees in Oman. International Journal of Management 11(11), 714-722.

Sanchez, D. O. (2019). Sustainable Development Challenges and Risks of Industry 4.0: A literature review. 2019 Global IoT Summit (GIoTS) (pp. 1-6, doi: 10.1109/GIOTS.2019.8766414). Aarhus, Denmark: IEEE.

Shafi, M., Zoya, gLei, Z., Song, X., \& Sarker, M. N. (2020). The effects of transformational leadership on employee creativity: Moderating role of intrinsic motivation. Asia Pacific Management Review, 25(3), 166-176.

Shayah, M. H., \& Sun, Z. (2019). Employment in the Gulf Cooperation Council (GCC) Countries - Current Issues and Future Trends. 2nd International Conference on Social Science, Public Health and Education (SSPHE 2018) (pp. 412-415). Atlantis Press.

Yue, C. A., Men, L. R., \& Ferguson, M. A. (2019). Bridging transformational leadership, transparent communication, and employee openness to change: The mediating role of trust. Public Relations Review, 45(3), 101779 https://doi.org/10.1016/j.pubrev.2019.04.012.

Zaidan, E., Al-Saidi, M., \& Hammad, S. H. (2019). Sustainable development in the Arab world - is the Gulf Cooperation Council (GCC) region fit for the challenge? Development in Practice 29(5), 670-681.

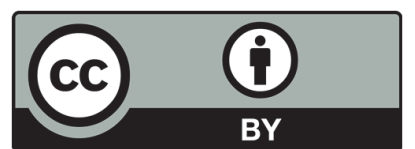

(C) 2021 by the authors; licensee Growing Science, Canada. This is an open access article distributed under the terms and conditions of the Creative Commons Attribution (CC-BY) license (http://creativecommons.org/licenses/by/4.0/). 